\title{
Use of Various concentrations of plant growth regulator (PGR) of Sweet Corn on the Growth and Production of sweet potato (Ipomoea batatas L.)
}

\author{
Ambo Upe
}

Faculty of Agriculture, PuangrimaggalatungSengkang University, South Sulawesi Province, Indonesia 90915

\begin{abstract}
The use of Plant Growth Regulating can be sourced from synthetic products and products made from natural or organic ingredients. This study aims to determine the effect of the use of various plant growth regulating (PGR) concentrations of sweet corn on the growth and production of Sweet Potatoes. The study was conducted in Wiringpalennae Sub-District, Tempe Subdistrict, Wajo Regency, South Sulawesi Province, Indonesia 2018. The method used was Randomized Block Design (RBD), consisting of four (4) treatments, namely without PGR (zo), PGR $3 \mathrm{ml} / \mathrm{l}$ water (z1), PGR $5 \mathrm{ml} / \mathrm{l}$ water (z2), and PGR $7 \mathrm{ml} / \mathrm{l}$ water (z3). Each treatment was repeated three times so that the number of treatment combinations was 12 combinations. The results of the study indicate that the administration of $7 \mathrm{ml} / \mathrm{l}$ of water in sweet potato produced an average production offresh tuber 60.51 that.
\end{abstract}

Keywords-Growth, PGR Sweet Corn, Production, Sweet Potatoes.

\section{INTRODUCTION}

Sweet potato (Ipomoea batatas L) is a crop of potatoes group, originally from Latin America (Widowati et al., 2010). Sweet potato plants in Indonesia are one of the most important plants, both as an alternative staple food in the dry season and as an additional food in order to diversify food ingredients. Indonesian sweet potato production can be said to be still low. The results of the wet bulb on average at a rate of as much as 15.20 Notional 2014 tons per hectare harvested area of 156758 ha with a total production of 2,382,658 million tons, while in 2015 increased by 16.10 tons per hectare, while harvested area decreased namely 143,125 ha with a total production of 2,297,634 million tons (BPS, 2016). According to Astawan and Widowati (2007) that with advanced technology some superior varieties of sweet potatoes can produce more than 30 tons of wet bulbs / ha.

Efforts to increase sweet potato production are still being carried out, so that efforts can be taken with various kinds of technology packages, one of the ways that can be done to achieve high production goals is through the provision of Plant Growth Regulating (PGR). Along with the current development of agriculture towards sustainable agriculture, it is directed to the actors of farming to use organic matter as a source of nutrients and Plant Growth Regulating (PGR) to increase plant growth and yield. The use of Plant Growth Regulating can be sourced from synthetic products and products made from natural or organic ingredients. Organic farming in a broad sense is an agricultural production system that relies on natural materials and avoids or limits the use of synthetic chemicals, especially plant growth regulators, with the aim of providing agricultural products (especially food) that are safe for the health of producers and consumers and maintain environmental balance by maintaining its natural cycle.

Plant growth regulator is an organic compound instead of nutrients in low concentrations can encourage, inhibit or qualitatively alter plant growth and development (Widyastuti and Tjokrokusumo 2001 in Asrijal et al., 2018a). One source of PGR can be used to stimulate plant growth can be obtained from the seeds of sweet corn crop is processed and then fermented in liquid form so it can function as a plant growth regulator. According to Asrijal at al. (2018b), Results of research on the use of plant growth regulator (PGR) sweet corn with a concentration of $1 \mathrm{ml} / 1$ of water on onion yield an average production of 12:08 $\mathrm{t} \mathrm{ha}^{-}$ 1 . 


\section{MATERIALS AND METHODS}

The study was conducted in Leweng Village, TakkalallaSubdistrict, Wajo District. The method used was Randomized Block Design (RBD), consisting of four (4) treatments, namely without PGR (zo), PGR $3 \mathrm{ml} / 1$ water $\left(\mathrm{z}_{1}\right)$, PGR $5 \mathrm{ml} / 1$ water $\left(\mathrm{z}_{2}\right)$, and PGR $7 \mathrm{ml} / 1$ water $\left(\mathrm{z}_{3}\right)$. Each treatment was repeated three times so that the number of treatment combinations was 12 combinations. Data were analyzed according to Gaspersz (1991).

\section{RESULTS AND DISCUSSION}

3.1. Research result

3.1.1. Number of Bulbs

The results of the average observation of the number of sweet potato tubers and their variance showed that the treatment of various concentrations of sweet potato PGR on the number of sweet potato tubers showed no significant effect (Fig. 1).

Number of Bulbs (bulbs)

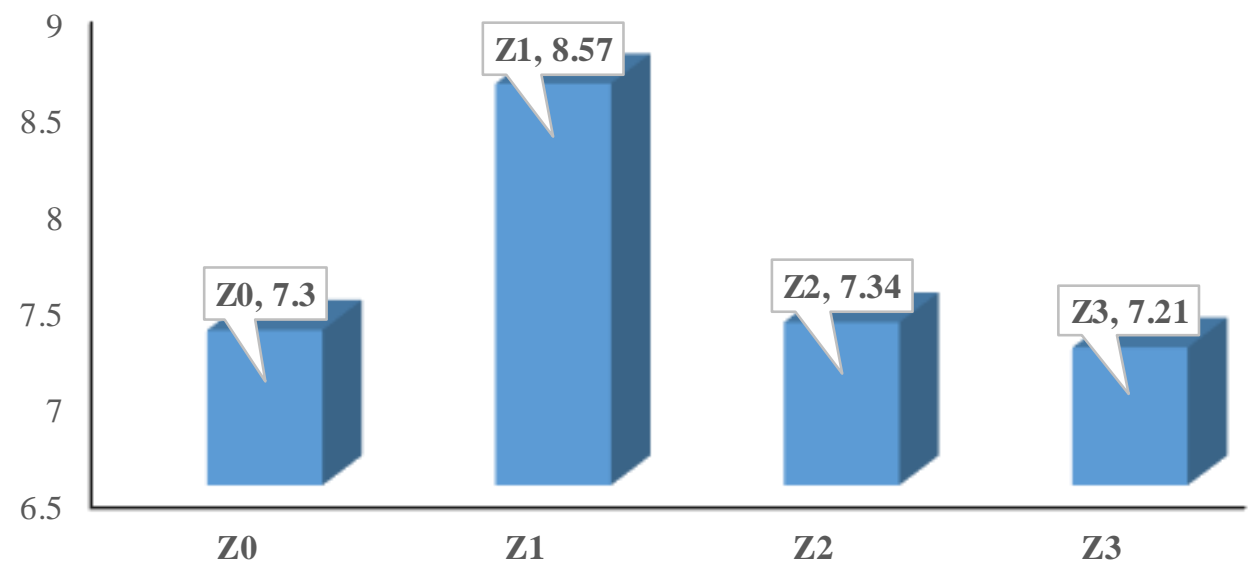

Fig. 1. Average diagram of observations of the bulbs number of Sweet Potatoes.

\subsubsection{Bulb Diameter}

The results of the average observation of sweet potato tuber diameter and variance showed that the treatment of various concentrations of PGR sweet corn on the tuber diameter of sweet potatoes showed no significant effect (Fig. 2).

- Bulb Diameter (mm)

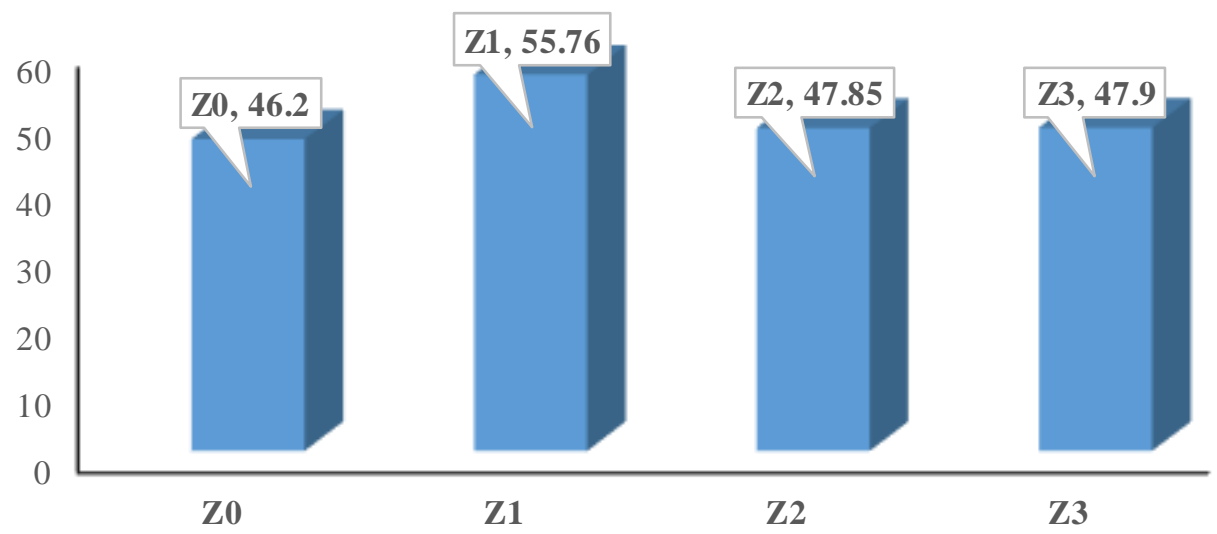

Fig. 2. Average diagram of observed of the bulb diameter of Sweet Potatoes 
3.1.3. Production per hectare

The results of the observation of the average production per hectare of sweet potato and its variance showed that the treatment of various concentrations of PGR sweet corn to the production per hectare of sweet potato showed a nonsignificant effect (Fig. 3).

\section{- Production Per Hectare}

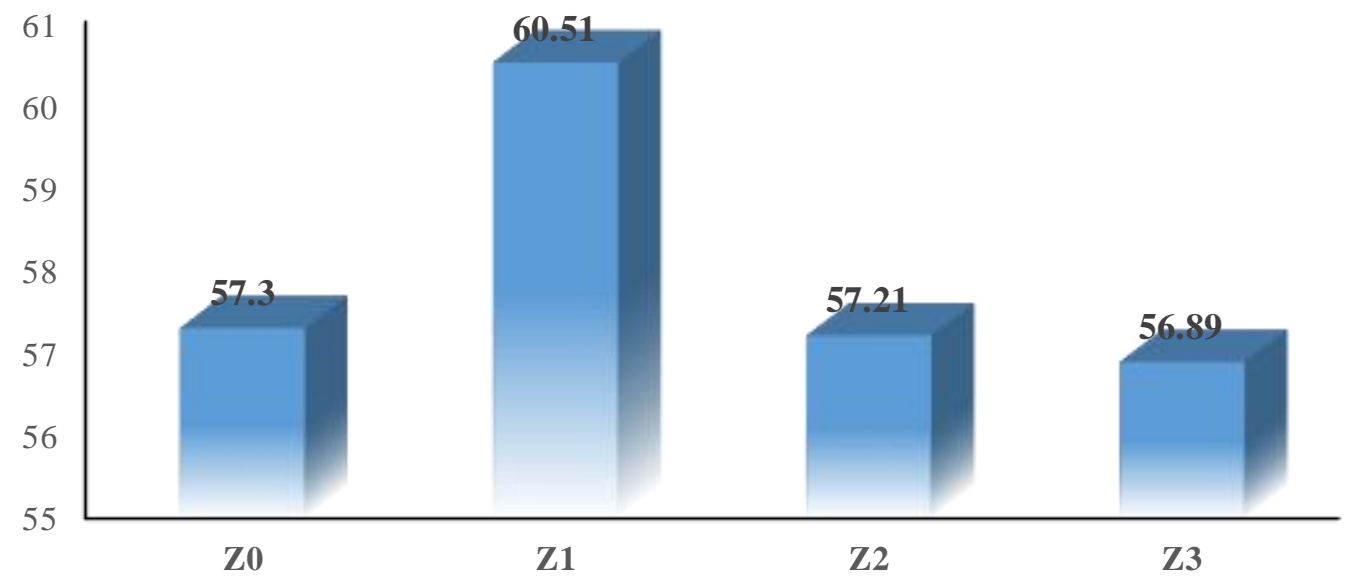

Fig. 3 Average chart of production observations per hectare of Sweet Potatoes (tons)

\subsection{Discussion}

Based on the results of research and analysis of data on the use of various concentrations of plant growth regulator (PGR) sweet corn on the growth and production of sweet potato shows that the parameter observation bulb number, diameter bulb and bulb production per hectare shows the results of the highest average in the treatment of PGR concentration of $3 \mathrm{ml} / 1$ water, respectively 8.57 bulbs per plant (Fig. 1), $55.76 \mathrm{~mm}$ bulb diameter (Fig. 2), and $60.51 \mathrm{t}$ ha $^{-1}$ (Fig. 3). This is caused because the content of plant growth regulator, auxin and gibberellin primarily of sweet corn extract is able to stimulate the growth and development of sweet potato bulbs.

According to Manik (2011). Auxin serves to help in the process of accelerating growth, both root growth and stem growth, accelerating germination, helping in the process of cell division, accelerating fruit ripening, reducing the number of seeds in the fruit. High levels of giberelin will stimulate cell division and elongation at the apex of the shoot, especially in the meristematic cells, thus spurring vegetative growth (Komariyah, 2012).

According to Soelaiman (2012). Two groups of growth regulators that are very important in tissue culture are auxin and cytokinin. Auxin is a growth regulator that plays a role in root formation, callus, inhibitory shoot formation inhibitors and axillary buds, and cell differentiation. Low concentration of gibberellin does not stimulate root formation, but at high concentrations stimulates root formation (Jauhar et al., 2013). (Karadeniz et al., 2006); (Pandingan and Nainggolan, 2006) Gibberellins function in the process of seed formation, which stimulates the formation of pollen (pollen), enlarges fruit size, stimulates flower formation, and ends the period of seed dormancy.

\section{CONCLUSIONS}

The treatment plant growth regulator at a concentration of 3 $\mathrm{ml} / 1$ of water gives an average yield higher with fresh bulb production $60.51 \mathrm{t} \mathrm{ha}^{-1}$,

\section{ACKNOWLEDGEMENT}

The author is grateful to the General Chairperson of the SengkangPuangrimaggalatung University for financial support through the research funding Mandiri 2018.

\section{REFFERENCES}

[1] Asrijal, ElkawakibSyam'un, Yunus Musa, and Muh. Riadi, 2018a. Characterization, Identification, and Analysis of Plant Growth Regulator (PGR) Conditions to Four Types of Free Clean Maize. Int. J. Curr. Res. Biosci. Plant Biol. Vol. 5 No. 4, p. 1723. doi.org/10.20546/ijcrbp. 2018.504.003.

[2] Asrijal, ElkawakibSyam'un, Yunus Musa, and Muh. Riadi, 2018b. Effect of Multiple of Plant Growth Regulator from Free Clean Maize to Growth and 
Production of Red Onion (Allium ascalonicum L.).

Int. J. Curr. Microbiol. App. Sci. Vol. 7 No. 5, p. 1824-1835. doi.org/10.20546/ ijcmas. 2018.705.215.

[3] AstawandanWidowati, 2007. Evaluation of Nutritional Quality and Glysemic Index of Sweet Potatoes as, a Fundamental for Fuctional Food Development. The European Journal of Technology and Advanced Engineering Research (In press).

[4] BPS - Statistics Indonesia, 2016. Indonesian Statistical(Statistical Yearbook of Indonesian, 2016). Publication Number:03220.1509. BPS Catalog: 1101001. Number of Pages: xxxviii+670pages. ISSN: 0126-2912. www.bps.go.id

[5] Gaspersz,.1991. MetodePerancanganPercobaan. Penerbit, CV. Armico, Bandung Indonesia.

[6] Jauhar, Aritonang, I., and kuswardani, I., 2013. Hormone Agribusiness. Organic Agriculture Clinic Celestial Clinic. Garut regency, West Java, Indonesia.

[7] Karadeniz, S,F., Topeuoglu, and Inan, S., 2006. Auxin, gibberellin, cytokinin and abscisic acid production in some bacteria. World J. of Microbiology \& Biotechnology 22:1061-1064.

[8] Komariyah, S., 2012. kandungan zat pengatur tumbuh daundanpolainfloresen bunga pada jarak pagar (Jatrophacurcas L.) Andromonoecious. (Skripsi). Departemen Biologi. Fakultas MIPA, IPB.

[9] Manik, A.J., 2011. Pengaruh Zat Pengatur Tum buh difenokonazol d anziramter hadappertum buhandan produksipadisawah (Oryza sativa L). (skripsi). Fakultas Pertanian. Institut Pertanian Bogor.

[10] Pandingan, S., and Nainggolan, T., 2006. The effect of GA3 and coconut water on the growth of orchid plant planlet (Dendrobiumsp) in vitro. $J$. of Communication Research, 18 (2): 30-33.

[11] Widowati, S., H.Herawati, BAS Santosadan H.A. Prasetia. 2010. Pengaruh Penggunaan PatiUbiJalar (IpomeaBatatas L) HMT Terhadap Sifat Fungsional Rasbi (BerasUbiJalar). 